\title{
Modeling neoplastic disease with spheroids and organoids
}

\author{
Michele Zanoni", Michela Cortesi, Alice Zamagni, Chiara Arienti, Sara Pignatta and Anna Tesei (D)
}

\begin{abstract}
Cancer is a complex disease in which both genetic defects and microenvironmental components contribute to the development, progression, and metastasization of disease, representing major hurdles in the identification of more effective and safer treatment regimens for patients. Three-dimensional (3D) models are changing the paradigm of preclinical cancer research as they more closely resemble the complex tissue environment and architecture found in clinical tumors than in bidimensional (2D) cell cultures. Among 3D models, spheroids and organoids represent the most versatile and promising models in that they are capable of recapitulating the heterogeneity and pathophysiology of human cancers and of filling the gap between conventional 2D in vitro testing and animal models. Such 3D systems represent a powerful tool for studying cancer biology, enabling us to model the dynamic evolution of neoplastic disease from the early stages to metastatic dissemination and the interactions with the microenvironment. Spheroids and organoids have recently been used in the field of drug discovery and personalized medicine. The combined use of 3D models could potentially improve the robustness and reliability of preclinical research data, reducing the need for animal testing and favoring their transition to clinical practice. In this review, we summarize the recent advances in the use of these 3D systems for cancer modeling, focusing on their innovative translational applications, looking at future challenges, and comparing them with most widely used animal models.
\end{abstract}

Keywords: Cancer, 3D models, Tumor microenvironment, Organoid, Spheroid, Drug discovery

\section{Introduction}

Despite the substantial progress made in the last few decades in improving cancer diagnosis, prevention, and treatment, there are still numerous obstacles to overcome to further enhance the quality of life and survival of cancer patients [1-4]. Currently, $<10 \%$ of new anticancer drug candidates entering phase I trials are eventually approved by the Food and Drug Administration (FDA) [5], with cancer having the lowest approval rate of new drugs with respect to other therapeutic areas [6]. One of the major challenges facing the development of new anticancer treatments is the transition of preclinical breakthroughs from "bench to bedside" [7].

\footnotetext{
*Correspondence: michele.zanoni@irst.emr.it; anna.tesei@irst.emr.it Biosciences Laboratory, Istituto Scientifico Romagnolo per lo Studio e la Cura dei Tumori (IRST) IRCCS, Meldola, Italy
}

(c) The Author(s). 2020 Open Access This article is licensed under a Creative Commons Attribution 4.0 International License, which permits use, sharing, adaptation, distribution and reproduction in any medium or format, as long as you give appropriate credit to the original author(s) and the source, provide a link to the Creative Commons licence, and indicate if changes were made. The images or other third party material in this article are included in the article's Creative Commons licence, unless indicated otherwise in a credit line to the material. If material is not included in the article's Creative Commons licence and your intended use is not permitted by statutory regulation or exceeds the permitted use, you will need to obtain permission directly from the copyright holder. To view a copy of this licence, visit http://creativecommons.org/licenses/by/4.0/ The Creative Commons Public Domain Dedication waiver (http://creativecommons.org/publicdomain/zero/1.0/) applies to the data made available in this article, unless otherwise stated in a credit line to the data.

It is generally accepted that experimental models are essential tools in the field of cancer research. However, the majority of cancer models used in drug discovery experiments poorly recapitulate the complexity and heterogeneity of human tumors [8], where both genetic and microenvironmental factors contribute to disease progression, response to therapy and metastatic spread [9].

Traditional bidimensional (2D) cell cultures initially developed by Harrison in the early 19th century [10] played an important role in establishing basic tumor biology research and continue to be routinely used thanks to their wide availability, easy handling, reproducibility, and low cost (Table 1) [11-13]. However, a major drawback of cell models are their failure to mimic the heterogeneity of original tumors [13]. Indeed, the procedures used for the generation of $2 \mathrm{D}$ cell cultures from primary tumor specimens are extremely inefficient, 
Table 1 Main features of preclinical cancer models

\begin{tabular}{|c|c|c|c|c|}
\hline Features & Cell culture & Spheroids & Organoids & PDXs \\
\hline Cost & Low & Low & Medium & High \\
\hline Time & Low $^{*}$ & Low $^{*}$ & Medium ${ }^{*}$ & High $^{*}$ \\
\hline Easy handling & +++ & ++ & + & - \\
\hline Success rate & High & High & Medium & Low \\
\hline Throughput potential & High & High & Medium & Low \\
\hline Tumor heterogeneity & No retention & Partial retention & Retention & Retention \\
\hline Genetic manipulation & +++ & +++ & +++ & - \\
\hline Human immune components & - & + & + & - \\
\hline Tumor-stroma interaction & - & ++ & ++ & +++ \\
\hline
\end{tabular}

Features are scored as follows: ${ }^{*}$ Low $\left(<1\right.$ month), ${ }^{*}$ Medium (1-3 months), ${ }^{*}$ High (several months). (+++) optimal, (++) good, (+) sufficient, $(-)$ not suitable

permitting the in vitro selection and expansion only of clones capable of growing in flasks or petri dishes [7, 14]. Moreover, cells cultured in vitro for several passages leads to substantial and unpredictable genetic changes [13], with a cell morphology barely resembling that observed in vivo $[1,15]$. Consequently, the use of animals for experimentation has intensified, increasing the overall length and cost of the drug discovery process. Several animal models have been generated to study human cancers as they do not have some of the drawbacks of 2D cell cultures (i.e., lack of stroma, vasculature, and immune components), and among these, mice models are the most widely used.

Transgenic mice can be generated to study genes involved in cancer development and/or to test innovative targeted therapy strategies. Moreover, patient-derived xenografts (PDXs) and tumor xenografts have been developed to more closely resemble the complexity of clinical tumors [16]. Despite the undeniable importance of animal models, it must also be underlined that they, like cell cultures, have some drawbacks. In particular, their genomic and immune profile does not exactly match that of humans [17], especially in mice PDXs where tumors may undergo mouse-specific evolution [18]. Furthermore, they are very resource- and time-consuming models to develop, and their uses are limited because of feasibility and ethical issues (Table 1).

In the past few decades, enormous progress has been made in the development of new cancer-mimicking technologies. Models such as cell co-cultures, threedimensional (3D) cultures and patient-derived tumor organoids closely resemble tumor cytoarchitecture and also have the advantage of mimicking tumor behavior, which is heavily dependent on environmental signals, cell-cell interactions and the extracellular matrix (ECM) [19-21].

In the present review, we describe the current state-ofthe-art in the use of 3D cell culture technology for cancer modeling, focusing on the potential innovative translational applications of scaffold-free 3D models and highlighting their strengths and weaknesses.

\section{D cancer modeling approaches}

An ideal 3D model to study cancer biology should resemble tumor tissue-specific architecture, and its pathophysiological microenvironment where tumor cells show many of the in vivo characteristics such as proliferation, differentiation, motility, and metabolism [22]. Solid tumors develop through the interaction between multiple cell and non-cell components, exploiting mechanisms similar to those found in the early stages of developing organs [23, 24]. Accordingly, tumors are considered as abnormal organs [23] displaying several biochemical gradients (i.e., oxygen, metabolites) and different physical properties that substantially impact cell behavior, resulting in a heterogeneous response to treatment $[1,25,26]$. Tumor cells in vivo are surrounded by different cell types (i.e., immune cells, stromal cells, endothelial cells) and other extracellular components (i.e., ECM, metabolites, extracellular vesicles (EVs), growth factors, cytokines) that constitute the tumor microenvironment (TME) [23]. Taking this into account, several methods to "assemble" in vitro 3D culture models have been developed to recapitulate in vivo suboptimal growth conditions and to study in depth the multifaceted features of the dynamic microenvironment of the tumor. These methods are usually categorized into two main classes: scaffold-based and scaffold-free systems.

Although the description of scaffold-based 3D models is beyond the scope of the present review, it must be underlined that they have undeniable advantages (i.e., they can be constituted by synthetic or naturally derived biopolymers mimicking the interaction between cancer cells and the ECM, providing a structural/physical support for the 3D culture) [1]. The biochemical and mechanical properties of the materials used in these models strongly affect cellular behavior [22, 27]. Moreover, physical properties such as stiffness, porosity, and surface chemistry, but also biological properties (i.e., biodegradability and cell compatibility) vary dramatically among the wide variety of biomimetic materials available 
[28], often making it difficult to obtain a controlled matrix and good reproducibility of biomaterials [28]. Indeed, the main issue in using these models is the appropriate selection of the 3D scaffold materials on the basis of the desire application.

Conversely, scaffold-free systems usually refer to selfassembled models in which cells aggregate and interact $[1,22,29,30]$. These 3D models have emerged as a pioneering approach in the field and are being used increasingly in cancer models and drug development studies. In fact, 3D scaffold-free modeling has been widely used in solid tumors derived from several epithelial tissues, such as breast, lung, prostate, or colorectal cancer [1]. With regard to non-epithelial tumors, in particular, sarcomas, obtaining 3D models (such as spheroids or organoids) have proven to be more complicated and challenging because of the extreme heterogeneity of the cells composing them, as highlighted by Drost et al. [7]. However, great efforts made by researchers to overcome the difficulties in generating 3D sarcoma models have led to the publication of several studies using sarcoma-derived spheroids (Fig. 1, Table 2). This bodes well for the attainment of more sophisticated 3D models such as sarcoma organoids, which would represent an important step forward in the fight against one of the most feared class of tumors.

In the following sections, we will focus on the two most common models used for cancer research (i.e., spheroids and organoids), highlighting differences and discussing related strengths and weaknesses.

\section{Spheroid model}

Tumor spheroids, one of the most versatile and common scaffold-free models [1, 29], are typically obtained from single-cell suspensions that are self-assembling or forced to aggregate. These 3D microtissues are used to model a wide variety of tumors [60-63], reproducing, in particular, avascular tumor mass microregions [64], intervascular domains, and micrometastases [65, 66]. Tumor spheroids of appropriate dimensions ( $>500 \mu \mathrm{m}$ in diameter) resemble the complex tumor scenario as they are composed of several specialized areas and layers where cells have different phenotypic, functional, and metabolic behaviors (Fig. 2). In particular, they display a well-organized spatial architecture with an external proliferative layer, an intermediate zone composed of quiescent and senescent cells and an inner apoptotic and necrotic core resulting from the impaired distribution of nutrients and oxygen in these areas $[1,30,67]$. Spheroid volume increases exponentially in the early stages and is followed by a period of "spheroidization/stabilization" in which the spheroids reach a sort of equilibrium, becoming more regular in shape and decreasing in volume (Fig. 2) [1, 29]. This latter phase is important for the development of the functional and structural organization of the spheroid itself [30, 64, 68]. Tumor cells within the spheroid closely interact with each other and such cell-cell interactions affect cancer cell behavior in terms of proliferation, survival, and response to therapy [69]. Cell-cell cohesiveness is enforced by the formation of desmosomes and dermal junctions [70] through the activation of adhesion receptors such as E-cadherins [71], and the secretion of ECM proteins and proteoglycans (Fig. 2) [72]. The close interactions between cells coupled with the deposition of several ECM proteins (collagens, fibronectin, laminin, elastin tenascin) increase spheroid density, forming a physical barrier that prevents and limits the transport of drugs into the spheroid mass [73, 74]. In addition, the increased interstitial fluid pressure inhibits the penetration and distribution of anticancer compounds by convection [75]. During spheroid growth, gradients of oxygen, metabolites, nutrients, and $\mathrm{pH}$ are established, strongly influencing the therapeutic effects of various drugs (Fig. 2) [69, 74]. Cancer cells under hypoxic conditions modify their metabolism, switching from oxidative phosphorylation to anaerobic glycolysis, thus obtaining

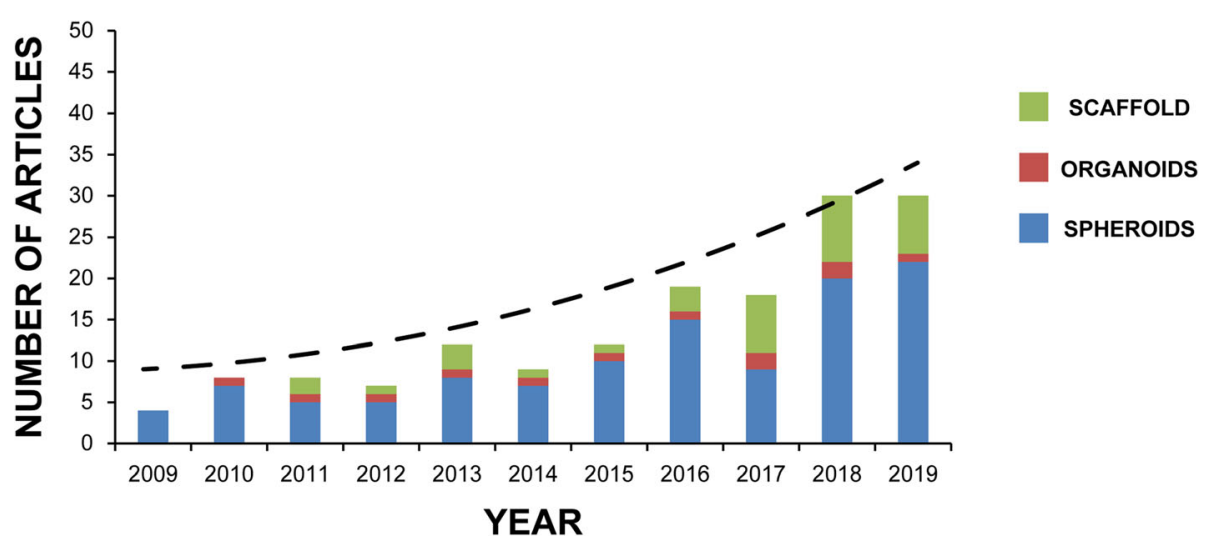

Fig. 1 Sarcoma 3D models. Search for articles appearing in PUBMED over the past 10 years (2009-2019) using the mesh terms "tissue scaffolds" AND "sarcoma" (green); "organoids" AND "sarcoma" (red); "spheroids, cellular" OR "spheroid" AND "sarcoma" (blue) 
Table 2 3D in vitro sarcoma models

\begin{tabular}{lll}
\hline Tumor subtype & Scaffold-free 3D models & Scaffold-based 3D models \\
\hline Osteosarcoma & {$[31-35]$} & {$[36-38]$} \\
Chondrosarcoma & {$[39-42]$} & {$[43,44]$} \\
Ewing sarcoma & {$[45-48]$} & {$[49-52]$} \\
Soft tissue sarcomas & {$[53-56]$} & {$[57-59]$} \\
\hline
\end{tabular}

Most recent and relevant references are reported

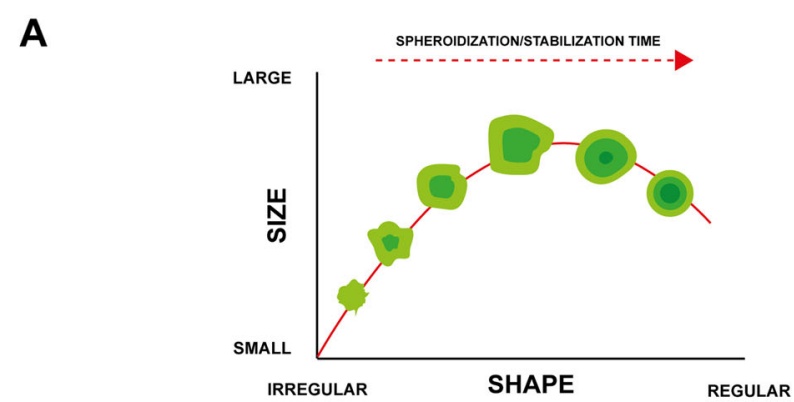

\section{B}

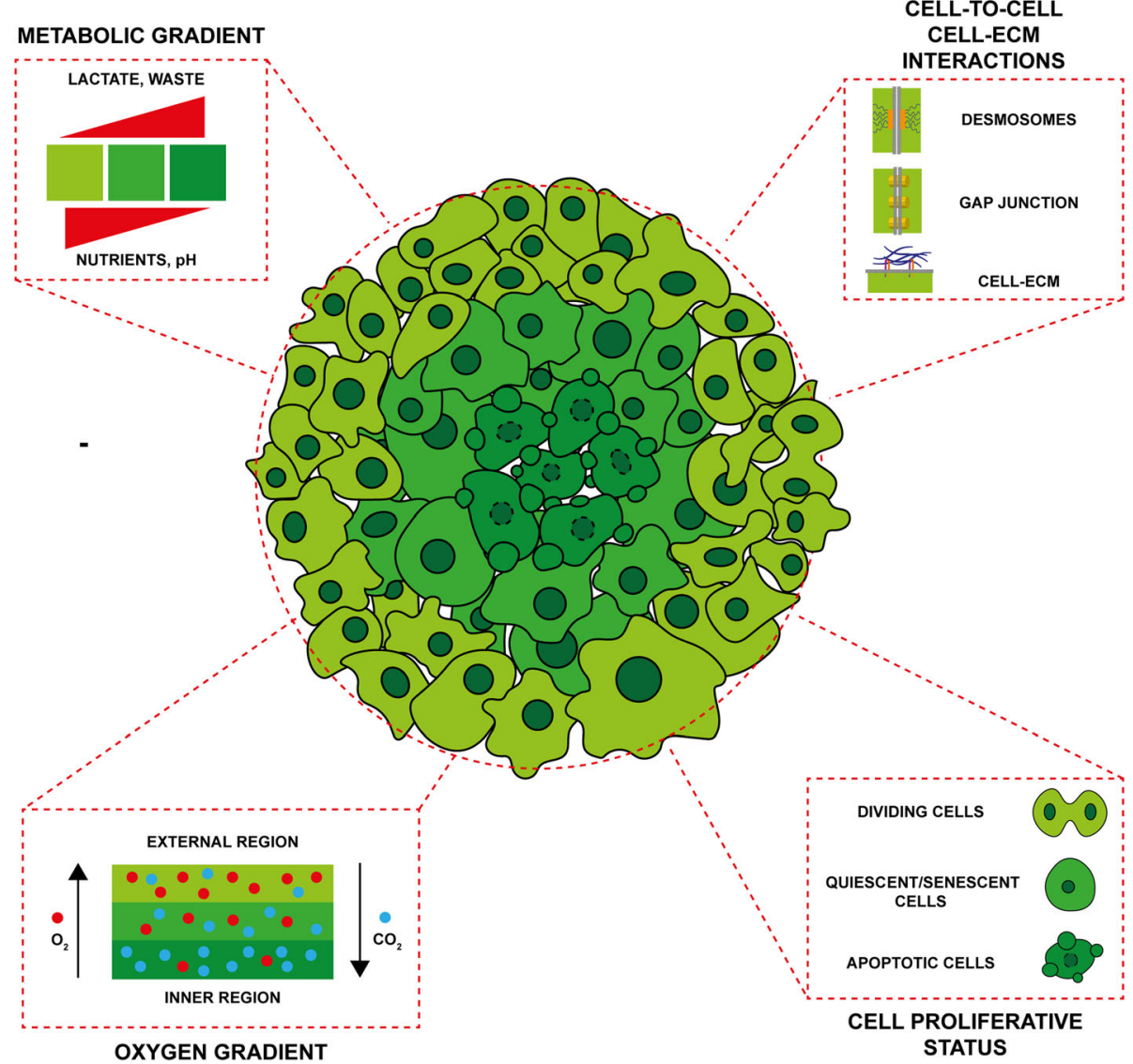

Fig. 2 Spheroid model. a Schematic representation of spheroid variation in shape and size over time. b Main characteristics of spheroid model. The spheroid is composed of several functionally differentiated areas and layers resulting from the impaired distribution of nutrients and oxygen. Tumor cells composing the spheroids interact with each other, developing a well-organized spatial architecture characterized by differences in phenotypic, functional, and metabolic status. 
energy by the conversion of pyruvate into lactate [76]. The release of lactate contributes to the acidification of the inner areas of the spheroids [77, 78], altering several cellular processes such as migration, immunomodulation, and chemoradiotherapy resistance $[79,80]$. Low $\mathrm{pH}$ directly affects the efficacy of some anticancer drugs (e.g., doxorubicin, vinblastine, methotrexate, anthraquinone) reducing intracellular uptake and tissue penetration through the alteration of their net charge [81-83]. The acidic microenvironment coupled with the lack of oxygen and nutrients are responsible for the quiescent/senescent state of the cancer cells in the deepest regions of the spheroid mass, the same phenomenon that occurs in in vivo tumors. Such cells continue to produce cytokines and growth factors but display a reduced proliferative state, making them more resistant to drugs usually employed to target cells with high proliferative rate (e.g., taxanes, cisplatin, oxaliplatin) [84, 85]. Conversely, the hypoxic environment contributes to the development of resistance to drugs requiring oxygen to induce cell death (e.g., 5-fluorouracil, cisplatin, and irinotecan) and radiotherapy [86].

Currently, spheroid models can be classified on the basis of the type of cancer cells and cultured methods used and on the desired application.

\section{Multicellular tumor spheroids}

Multicellular tumor spheroids (MTS) are mainly generated from established cancer cell lines grown in conventional cell culture media supplemented with serum (Table 2) [87]. It thus follows that they can be considered an extension of the standard bidimensional culture of cancer cell lines showing a similar limited histological resemblance to the primary cancer. Their main differences with respect to bidimensional cell cultures, apart from the capacity to grow as spherical colonies in suspension culture, are that MTS replicate the metabolic and proliferative gradients of clinical tumors and show substantial multicellular chemoresistance, thus mimicking what happens in cancer patients [88]. Additional advantages of MTS over other 3D systems are cell clonality, ease of maintenance, and simplicity of genetic manipulation, making this model an appropriate tool for high-throughput drug testing [89]. Although several methods, mainly based on anchorageindependent technologies, have been developed to generate large amounts of MTS of different sizes and shapes, not all cell lines are capable of forming spheroids [90]. Indeed, each cell line and method chosen for use requires specific optimization. In particular, cell culture time and cell density are two important parameters influencing spheroid formation.

\section{Multicellular tumor-derived spheroids}

Multicellular tumor-derived spheroids (MTDS), also called tumorspheres [87], are usually obtained from dissociated tumor tissue and represent another spheroid model widely used in cancer research (Table 3). Like MTS, MTDS have a limited histological similarity to the primary cancer from which they are derived but differ from MTS mainly in terms of their enrichment in cancer stem cells (CSCs) or cells with stem cell-related features. CSC enrichment in MTDS cultures can be confirmed by functional assays that determine the tumorigenicity of spheroids (i.e., in vivo tumor-formation assays after transplantation into immunocompromised mice), their expression of CSC-related markers (i.e., $A L D H, C D 133, C D 44)$, and their pluripotency (i.e., ability to differentiate into tissue-specific cell lineages). From a methodological point of view, MTDS can be obtained with the same methods used to generate MTS, the main differences being the addition of specific tissuerelated growth factors and the use of serum-free culture medium. Specific growth factors are used to carefully reproduce stem cell-like states [91] for serum-free culture conditions, whereas serum is avoided because it is considered a differentiating factor (Table 3) [91]. MTDS have been widely used in in vitro studies on cancer stemness, and despite some uncertainty about the link between sphere formation and CSC phenotype, they are widely regarded as a surrogate method for CSC isolation and ex vivo expansion [92-96]. In particular, it has been hypothesized that CSCs are related to chemoresistance and metastatic spread, and some authors have pointed out that CSCs are, by their very nature, more resistant to xenobiotics and drugs than many of the malignant cells composing the tumor bulk [97, 98]. Such resistance is mainly due to the increased expression of aldehyde dehydrogenase (ALDH) enzymes, which are capable of metabolizing drugs [99], enhanced DNA damage response [100], and increased activity of ATP-binding cassette $(\mathrm{ABC})$ transporters [101]. Consequently, MTDS have predominantly been used to investigate CSC chemoresistance in vitro to shed light on the intrinsic drug resistance of advanced cancers.

\section{Integrating microenvironment: heterotypic spheroids}

It is known that solid tumors are composed not only of cancer cells, but also of stromal cells such as fibroblasts (or cancer-associated fibroblasts, CAFs), immune cells, lymphatic endothelial cells, vascular endothelial cells, pericytes, and adipocytes [102]. Although these cells are not malignant, their interactions with cancer cells in the tumor milieu foster tumor angiogenesis, proliferation, invasion, and metastasis and also mediate mechanisms of drug resistance [103]. Such interactions have been amply described in both solid and hematological tumors where the activation of several crucial pathways involved in DNA repair, proteasome activation, inflammation, ECM production, invasion, and caspase inhibition are enhanced [104]. 3D tumor spheroids can be optimized by coculturing cancer and stromal cells, such as fibroblasts 
[105], endothelial cells [106], or immune cells [107] to mimic the cellular heterogeneity of solid tumors and the resistance mediated by tumor-stromal cell interactions (Table 3). Of note, the direct interaction between stromal and cancer cells coupled with the release of cytokines, extracellular vesicles, and growth factors reconstitute the intricate signaling network of in vivo tumors [108]. Generally, spheroids composed of a single cell type are called homotypic spheroids, while those constituted by multiple cell types are known as heterotypic spheroids. Different stromal:cancer cell ratios have been tested to recapitulate specific tissue composition found in vivo [109]. In particular, fibroblasts represent one of the most abundant populations of stromal cells in the TME, contributing to tumor initiation, progression, metastasis, and response to therapy [108]. For this reason, heterotypic spheroids composed of tumor cells and CAFs are widely used in drug discovery studies [109-111].

\section{Organoid model}

Decades of research into developmental biology and organ physiology together with a deeper understanding of techniques for growing tissue ex vivo have improved our ability to recapitulate organogenesis cues in vitro, leading to the development of the organoid model [112, 113]. Recent years have seen a plethora of new techniques for growing tissue as 3D in vitro organotypic cultures and, in particular, for the development of diseasemodelling organoids. Organoids are a powerful in vitro system and are increasingly being used in a wide range of studies. They are defined as self-organized 3D structures derived from adult or embryonic stem cells mirroring the architecture and functionality of the tissue of origin or of the tissue from which they are derived [7, $112,114]$. The organoid structure reflects specific tissue characteristics in terms of distribution of differentiated cell types, global architecture, and tissue- and cellspecific functions [114]. Long-term organotypic cultures are established by supplementing the medium with a well-defined mixture of tissue-specific growth factors without feeder layers [115]. To date, organoid cultures have been established for a wide variety of human healthy tissues as well as for patient-derived tumor specimens, obtaining the so-called "tumoroid" model [7, 116]. Tumoroids reflect the genetic and phenotypic features of tumor epithelium such as heterogeneity and 3D spatial organization $[117,118]$. Numerous other features facilitate their use as a model to study cancer. In particular, being human-derived, they are not hampered by interspecies differences when used for disease modelling, which is the main drawback of using animal models. Furthermore, organoids can also be propagated in vitro and cryopreserved, facilitating the creation of an organoid biobank/library of different cancer subtypes from large numbers of patients, representing an extremely useful tool for preclinical studies [7, 116, 119, 120]. To date, long-term organoid cultures have been established from several healthy and cancer tissues (Fig. 3) including colon [121-125], breast [118, 126], liver [127, 128], lung [129, 130], pancreas [131, 132], endometrium [133], stomach $[119,134,135]$, prostate [136, 137], ovary [138], bladder [139, 140], kidney [141-143], brain [144, 145], bone [146, 147], and esophagus [148, 149].

\section{Organoids as models for personalized medicine and drug screening}

One of the main advantages of the organoid model is the possibility of obtaining healthy tissue and cancer tissue from the same patient, providing a powerful tool for predicting drug response in drug screening (Fig. 4). In particular, this model enables researchers to identify compounds preferentially targeting cancer cells rather than healthy ones, resulting in the selection of less toxic substances and thus decreasing the risk of side effects [7]. For example, liver organoids obtained from induced pluripotent stem cells (iPSCs) or healthy tissue can be used to evaluate the hepatotoxicity of new experimental drugs $[150,151]$ as they express fairly similar physiological levels of cytochrome P450 enzymes [152]. Similarly, iPSC-derived cardiac and kidney organoids can be used to perform toxicological studies $[153,154]$. However, a major hurdle in the development of tumoroids is the overgrowth of non-tumor components present in tumor specimens, which compromises the attainment of a model homogenous for a specific genetic or phenotypic feature. For example, in colorectal cancer, mutations involved in the activation of WNT signaling are

Table 3 Main features of the most common spheroid models used in preclinical cancer research

\begin{tabular}{|c|c|c|c|c|}
\hline Spheroid models & Cells of origin & Culture medium & Culture method & References \\
\hline $\begin{array}{l}\text { Multicellular tumor } \\
\text { spheroids (MTS) }\end{array}$ & Established cancer cell lines & $\begin{array}{l}\text { Conventional medium supplemented } \\
\text { with serum }\end{array}$ & Non-adherent conditions & {$[87]$} \\
\hline $\begin{array}{l}\text { Multicellular tumor- } \\
\text { derived spheroids } \\
\text { (MTDS) }\end{array}$ & $\begin{array}{l}\text { Cancer cells derived from } \\
\text { dissociated tumor tissue }\end{array}$ & $\begin{array}{l}\text { Medium without serum supplemented } \\
\text { with growth factors (e.g., FGF2, EGF) }\end{array}$ & $\begin{array}{l}\text { Non-adherent conditions } \\
\text { Pre-sorting of specific cancer cell } \\
\text { populations }\end{array}$ & [91] \\
\hline Heterotypic spheroids & $\begin{array}{l}\text { Cancer cells mixed with } \\
\text { stromal cells and/or immune } \\
\text { cells }\end{array}$ & $\begin{array}{l}\text { Conventional medium supplemented } \\
\text { with serum }\end{array}$ & $\begin{array}{l}\text { Non-adherent conditions } \\
\text { Physiological ratio cancer:stromal/ } \\
\text { immune cells to mimic clinical } \\
\text { tumors }\end{array}$ & [105-107] \\
\hline
\end{tabular}



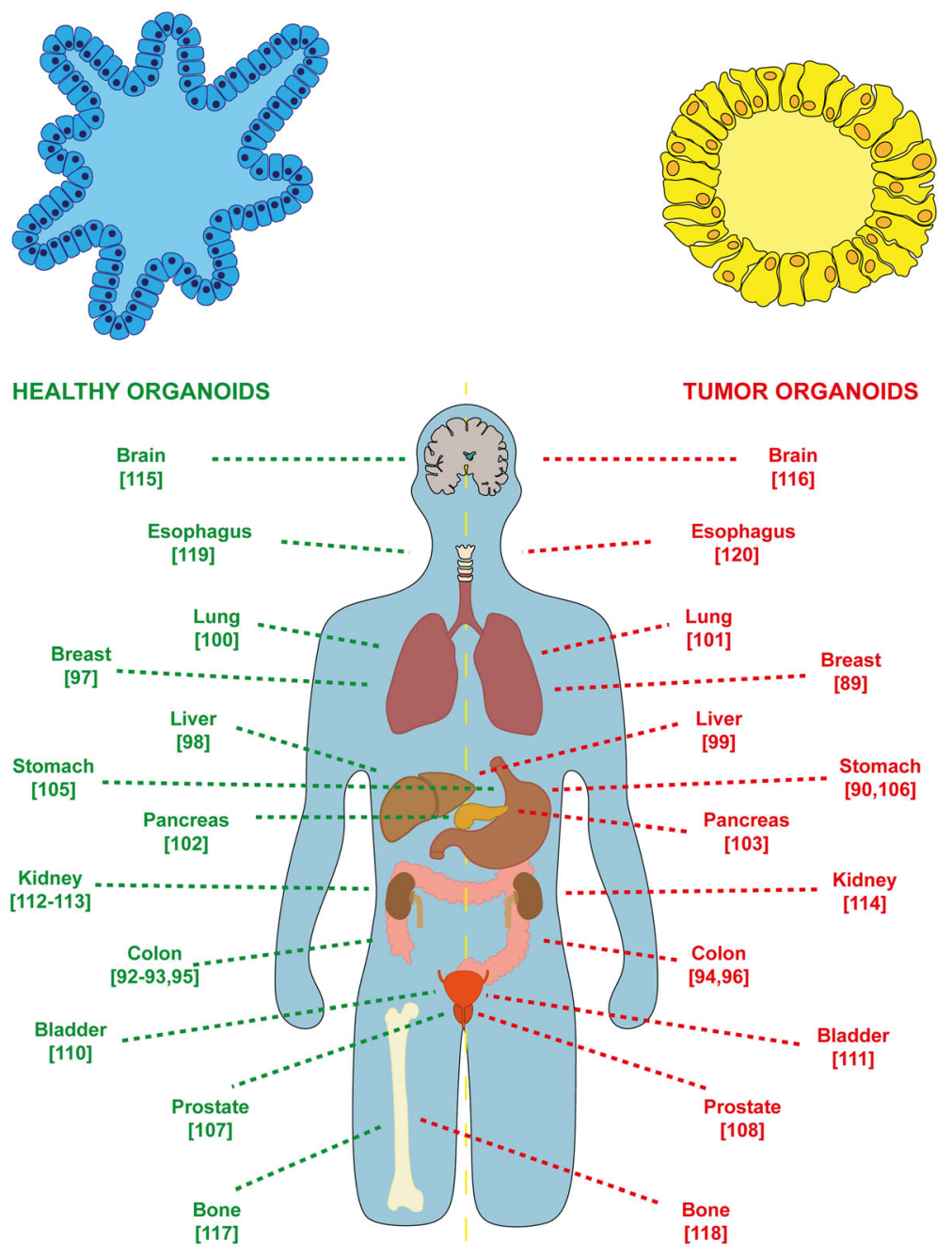

Fig. 3 Organoid model. Organoids currently established from healthy and cancer tissues. (References are indicated in brackets)

fairly common [123], and medium without WNT and Rspondins is needed to obtain WNT-mutated tumoroids [7]. Patient-derived organoids can also be used to detect epigenetic and/or genetic alterations underlying drug resistance (Fig. 4). Matching tumoroid and healthy organoid profiles can help to identify different mutation and protein patterns that could help to stratify patients for specific treatments [155]. In addition, tumor organoids derived from different regions of the same tumor have been used to study intra-tumor heterogeneity and to evaluate drug sensitivity of different tumor subclones [156].

\section{Organoids as a model to study tumorigenesis}

Organoids can also be used to investigate the role of mutational processes in tumorigenesis. It is known that cancer results from the accumulation of several mutations in specific genes involved in different cellular processes [157]. Recently, in this context, the use of healthy organoids coupled with gene editing technologies such as CRISPR-Cas9 has led to a better understanding of organ-specific mutagenic processes [158] resulting from the accumulation of key mutations during malignant transformation (Fig. 4) [159]. For example, the introduction of a combination of driver mutations in KRAS (activating mutations), APC, TP53, and SMAD4 (inactivating mutations) has been used to generate colorectal cancer (CRC) progression models [158]. When engrafted into mice, these mutated organoids grow as invasive cancer [160]. However, they spontaneously metastasize to the lungs and liver only when orthotopically transplanted into the cecum of the animals $[161,162]$, suggesting that advanced processes in carcinogenesis are heavily dependent on microenvironmental factors [125]. In another study, oncogenic mutations in CDKN2A, KRAS, TP53, and SMAD4 introduced into human pancreatic organoids transformed normal cells into cancer cells, 


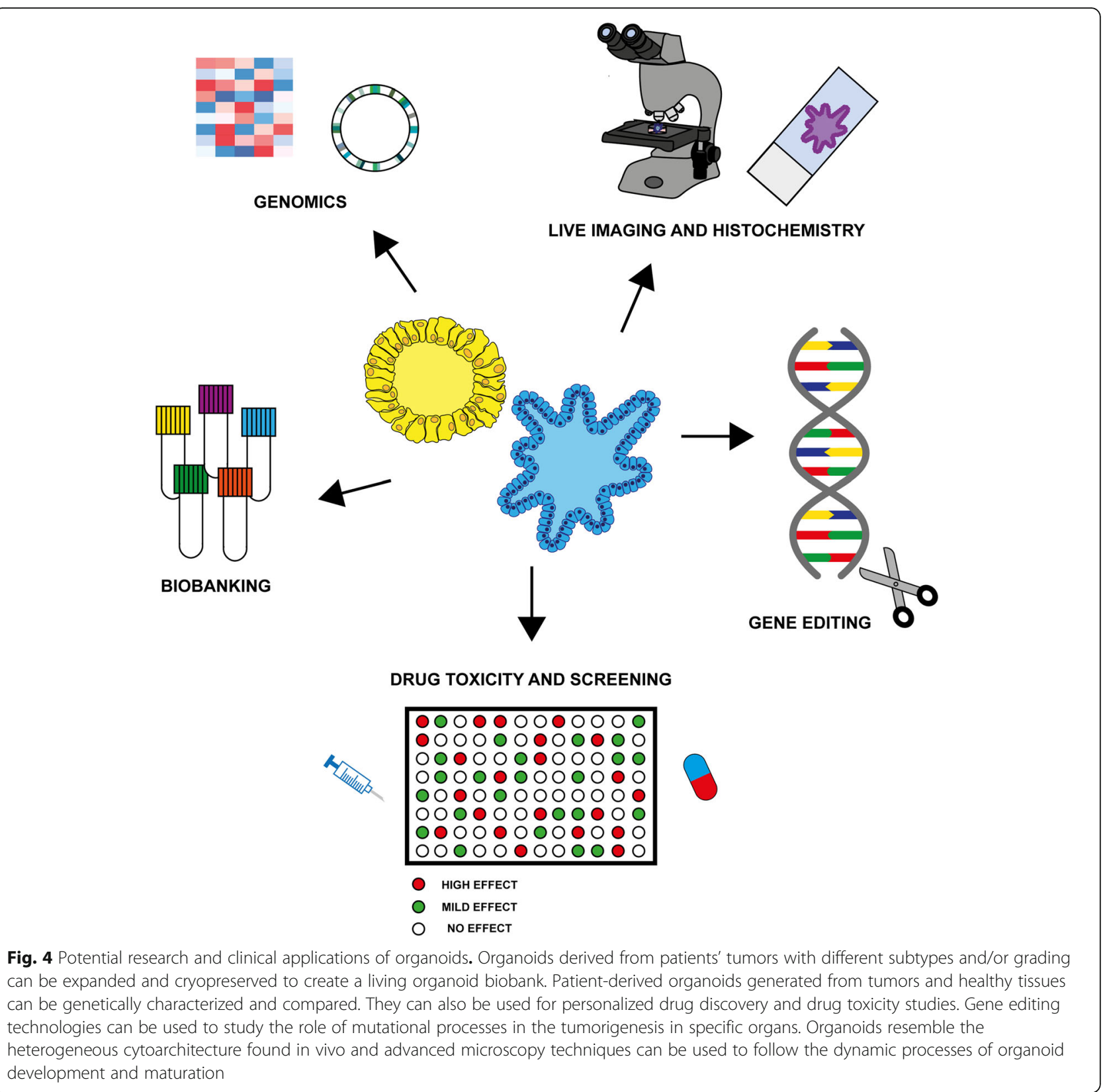

modelling primary and invasive pancreatic ductal adenocarcinoma when xenotransplanted in vivo [163].

Cancer organoids have also been used to model metastatic processes, in particular to investigate the different processes of invasion [164, 165]. For example, a study conducted on CRC organoids showed that inhibition of rho-associated protein kinase 2 (ROCK2) improved collective invasion in its early stages [166].

\section{Integrating the microenvironment in organoids: current advances}

The TME plays a pivotal role in cancer progression and is crucial for tumor survival, mainly through the production and release of supporting factors [167]. In particular, the TME contributes to tumor heterogeneity, strongly affecting the adaptive cellular response which is dependent on tumor grade and stage and treatment history [168]. There are still no preclinical models that fully recapitulate patient-specific stromal, immune, structural, chemical, and molecular aspects of the heterogeneous microenvironments to which cancer cells are sequentially exposed during the course of the disease [169]. In particular, organoids usually only contain progenitors and cells of epithelial origin, lacking other cell types such as fibroblasts, immune cells, and endothelial cells [170]. After many years of disappointing results, remarkable progression has 
been made in cancer immunotherapy, and several organoid-based models have been created to better our understanding on how the immune system eradicates tumor cells, facilitating a personalized immunotherapeutic approach [171]. Currently, two conceptually different organoid models are used-i.e., cancer organoids cultured directly from tumors preserving endogenous immune cells and other non-epithelial cell types (holistic approach) [172-175], and cancer organoids co-cultured with immune cell subsets isolated and separately expanded (reductionist approach) [176-178]. The two are equally valid approaches to understanding cell-cell interactions, modelling immune checkpoint blockade and testing CAR-T cell-mediated cytotoxicity and represent a highly informative platform for the development of cancer immunotherapy. In a recent study, Neal et al. developed a liquidair interface organoid system including native immune and stromal cells, enabling the reconstruction of the cytoarchitecture of different tumors [175]. The authors demonstrated that the $\mathrm{T}$-cell receptor repertoire is conserved between original tumors and organoids and that the PD1/PD-L1 immune checkpoint axis is functional in these models. In another study, murine pancreatic ductal adenocarcinoma cells were co-cultured with stromal stellate cells, the latter able to differentiate into CAFs expressing high levels of $\alpha$-SMA and inflammatory mediators such as IL-6 [179]. These findings were further investigated in human organoid models where CAFs support tumor growth, creating a niche enriched in Wnt-ligands [163]. Another interesting study described the development of human blood vessel organoids using pluripotent stem cells to model diabetic vasculopathy [180]. The model was characterized by a self-assembled capillary network composed of endothelial cells and pericytes surrounded by basement membrane [116] which, in vivo, recreate a perfused system comprising arterioles and venules [180]. This model provides a new opportunity for co-culture experiments aimed at investigating the interactions between cancer cells and the vascular system. Finally, another interesting approach to fully recapitulate the physical, dynamical, cellular, and biochemical features of the TME is the integration of organoids and organ-on-a-chip technologies. The latter are defined as microfabricated cell culture devices designed to reproduce key functional features of human organs in vitro [113] including the cytostructural organization of different cell types and the dynamics of flow perfusion. Each "organ functional unit" can be interconnected through microfluidic channels simulating multiorgan interactions $[181,182]$ and is a good model to study the metastatic processes. Recent studies have reported the potential of combining organoids and organon-a-chip models, taking advantage of the best features of both systems [170, 183, 184]. An important issue for organ development and growth is the continuous supply of nutrients and oxygen usually provided in vivo by blood vessels. To mimic this, Shirure et al. developed a tumor organoid-on-a-chip system creating a 3D perfusable blood vessel network capable of delivering nutrients and/or drugs to patient-derived breast cancer organoids [185]. This platform allowed the authors to simultaneously and dynamically observe cancer cell intravasation, migration, and proliferation and also to assess the response to specific chemo- and/or targeted therapy under physiological flow conditions. The complexity of the human body is also a consequence of dynamic interconnections between its components at different levels of organization. Although organoids provide good platforms that recapitulate the features of each single organ, a system of connections between each organoid is needed to better understand systemic processes, such as metastatic spread of cancer cells or systemic cytotoxicity of anticancer drugs. Recently, Skardal et al. used a multi-organ-on-a-chip system composed of liver and heart organoids perfused in a closed loop with a microengineered lung tissue to evaluate the cytotoxicity of the chemotherapeutic drug bleomycin [186]. Finally, another lung-brain-liver-bone-on-a-chip model was used to study the metastatic spread of primary lung cancer to these organs, highlighting a different spatiotemporal distribution of cancer cells in each organ [187].

\section{Animal models: still an indispensable tool for cancer research}

In vivo models to study human cancers have been widely used in cancer research for many years and represent an essential tool to better understand the complexity of cancer biology and to discover new methods of prevention, diagnosis, and treatment [188]. Many animal models can be used to recapitulate cancer more or less faithfully [189]. Less complex animal models such as Drosophila melanogaster [190], Caenorhabditis elegans [191], Xenopus laevis [192], and Danio rerio [193, 194] have contributed extensively to elucidating the molecular basis of the disease, although mice are the predominantly used model. Each animal model has its own characteristics, and researchers must choose the one that is best suited to the research question. Among less complex animal models, zebrafish Danio rerio has become a popular model to study developmental processes and human diseases and now also plays a prominent role in cancer research [195]. The main advantages of this model are its elevated fecundity, the formation of optically transparent embryos that develop outside the mother, with most of the main organs conserved among the other vertebrates in terms of architectural and cellular features (e.g., brain and bone marrow niches are well formed) [193, 196-198]. In addition, the development of transgenic fish strains has proven an exceptional tool for the study of oncogenes [196, 197]. Zebrafish have been 
used to investigate the role of a vast number of genetic alterations occurring in human cancers, leading to the identification of potential driver genes. A widely used method for testing tumorigenicity is that of transplanting tumor cells in vivo in a recipient that belongs to the same species (allograft) or to another species (xenograft) [193]. This is usually obtained by injecting human cancer cells into immunocompromised mice, with limitations in the resolution of imaged cells and in the number of animals that can be used. The zebrafish model overcomes such limitations: the small size coupled with the optical transparency of the embryos allows the visualization of growing tumors with single-cell resolution [198, 199]. Zebrafish embryos can be grown in multiwell plates and this, coupled with their low cost, highlight their potential as models for high-throughput screening of new anticancer drugs to increase the power of statistical analysis [200, 201]. This leads to more robust and reliable data before moving to mammalian models.

Mice are the predominantly used animals among mammalian models, and PDXs in particular have emerged as an important and promising platform for research into new cancer treatments and biomarkers $[16$, 202]. In PDXs, surgically derived patient tumor samples are implanted into immunodeficient mice, maintaining the original proportion of tumor and stromal cells $[16$, 116]. These models closely resemble the clinical tumor architecture and the characteristics of each patient's tumor, recapitulating the intertumor and intratumor heterogeneity of human cancers [16, 203, 204]. However, the use of only a small amount of the patient's tumor tissue results in an incomplete representation of the original tumor [205]. Indeed, more than $50 \%$ of mutations found in primary cancer tissue may not be detected, while some new mutations may appear during the early passages in PDXs [206]. Furthermore, the contribution of stromal microenvironment in PDXs remains controversial. Human TME components such as immune cells, vasculature, and stromal cells only survive for a short time, eventually being replaced by murine stroma [207]. This limits the time in which TME crosstalk can be studied [116]. In addition to mouse-specific tumor evolution $[7,16,18]$, another important limitations of PDX models is their limited engraftment efficiency based on tumor subtypes and grade [208]. Advanced tumor subclones may grow better than less advanced tumors in PDXs [209]. It is now known that orthotopic transplantation of tumor tissue provides more reliable PDXs than those obtained through heterotopic engraftment. In fact, there is evidence that the transplantation of primary tumor fragments in the corresponding anatomical position in mice leads to a local invasive behavior and the development of metastasis similar to that observed in humans [210, 211]. Metabolic differences were found in a comparison study between orthotopic and subcutaneous PDXs of pancreatic ductal adenocarcinoma, highlighting the importance of the location and the surrounding environment of the transplantation site [116, 212]. This approach remains time- and resourceconsuming and should be reserved for validating robust in vitro data. Despite this, animal model experimentation still represents a crucial part of cancer studies aimed at understanding tumor biology and at finding innovative therapeutic strategies. The advent of 3D models could constitute an important step forward in cancer research, filling the gap between traditional cell cultures and animal models (Fig. 5) and helping to reduce the use of

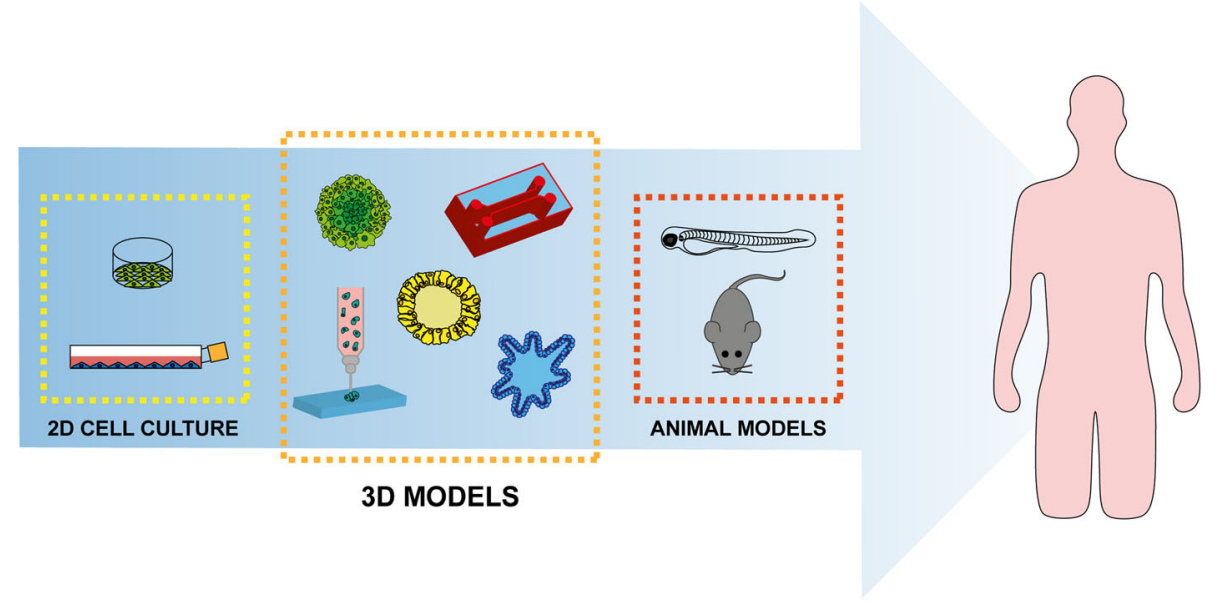

Fig. 5 Current preclinical cancer research. 3D systems combined with new technologies such as organ-on-a-chip and 3D bioprinting could fill the gap between traditional 2D cell culture and animal models, producing more reliable data while also reducing costs, time to results, and political/ ethical issues before their transition to clinical practice 
animals, especially in drug discovery and toxicity studies, before clinical trials in humans (Fig. 5). For now, animal models are still not fully replaceable and thus continue to be essential for cancer research.

\section{Conclusions}

Cancer spheroids and organoids have proven to more closely resembling the pathophysiological features of clinical tumors than 2D cell cultures, approaching the level of in vivo models. In particular, organoid models retain the cellular and molecular phenotypes of original patient tumors, providing a powerful tool to investigate the onset of disease, progression, and biology and the development of more effective and personalized anticancer therapies. However, further efforts are needed to increase the degree of complexity of such models to develop more sophisticated systems that take into account all the cellular, physical, and biochemical components of the TME. Within this context, organ-on-a-chip and bioprinting technologies in combination with spheroid and organoid models could constitute an enormous step forward in the area of tumor modelling, marking an exciting new era in the landscape of preclinical cancer research (Fig. 5). Together, these systems unite the cellular complexity of organoids with the precise spatial organization provided by 3D bioprinting and the structural, physical, mechanical, and perfusion cues reconstructed on organ-on-a-chip systems. However, animal models remain indispensable, and advances have also been made in this area with the development of humanized murine models [213]. In this setting, the introduction of human hematopoietic stem cells (HSCs) into severely immunodeficient mice (i.e., NOD/SCID/IL2Rcnull (NSG) mice), coupled with the engraftment of human cancer cells, has enabled the dynamic growth of tumors to be investigated in vivo in the presence of a competent human immune system [214]. The combined use of 3D models could represent the next step forward in in vitro research into the development of effective anti-tumor treatments, also reducing animal testing and consequently costs, time to results, and political and ethical issues. Improvement in the robustness and reliability of research data would consequently follow, increasing their transferability from bench to bedside.

\begin{abstract}
Abbreviations
3D: Three-dimensional; 2D: Bidimensional; FDA: Food and Drug Administration; EVs: Extracellular vesicles; ECM: Extracellular matrix; TME: Tumor microenvironment; MTS: Multicellular tumor spheroids; MTDS: Multicellular tumor-derived spheroids; CSCs: Cancer stem cells; ALDH: Aldehyde dehydrogenase; ABC: ATP-binding cassette; CAFs: Cancerassociated fibroblasts; iPSCs: Induced pluripotent stem cells; PDXs: Patientderived xenografts; CRC: Colorectal cancer; ROCK2: Rho-associated protein kinase 2; HSCs: Hematopoietic stem cells; NSG: NOD/SCID/IL2Rc null mice
\end{abstract}

\section{Authors' contributions}

AT and MZ conceived the idea for the research, designed the review, and drafted the first version of the manuscript. All of the authors participated in the drafting and revision of the manuscript, performed the literature review and read and approved the final version of the paper for submission.

\section{Funding}

This manuscript was not funded externally.

\section{Availability of data and materials \\ Not applicable}

Ethics approval and consent to participate

Not applicable

\section{Consent for publication \\ Not applicable}

\section{Competing interests}

The authors declare that they have no competing interests.

Received: 25 March 2020 Accepted: 2 July 2020

Published online: 16 July 2020

\section{References}

1. Zanoni M, Pignatta S, Arienti C, Bonafè M, Tesei A. Anticancer drug discovery using multicellular tumor spheroid models. Expert Opin Drug Discov. 2019;14:289-301.

2. Hutchinson L, Kirk R. High drug attrition rates-Where are we going wrong. Nat Rev Clin Oncol. 2011;8:189-90.

3. Sant S, Johnston PA. The production of 3D tumor spheroids for cancer drug discovery. Drug Discov Today Technol. 2017;23:27-36.

4. Caponigro G, Sellers WR. Advances in the preclinical testing of cancer therapeutic hypotheses. Nat Rev Drug Discov. 2011;10:179-87.

5. Nass SJ, Rothenberg ML, Pentz R, Hricak H, Abernethy A, Anderson K, et al. Accelerating anticancer drug development - opportunities and trade-offs. Nat Rev Clin Oncol. 2018;15:777-86.

6. Wong CH, Siah KW, Lo AW. Estimation of clinical trial success rates and related parameters. Biostatistics. 2019;20:273-86.

7. Drost J, Clevers H. Organoids in cancer research. Nat Rev Cancer. 2018;18: 407-18.

8. Kamb A. What's wrong with our cancer models? Nat Rev Drug Discov. 2005: 4:161-5.

9. Quail DF, Joyce JA. Microenvironmental regulation of tumor progression and metastasis. Nat Med. 2013;19:1423-37.

10. Harrison RG, Greenman MJ, Mall FP, Jackson CM. Observations of the living developing nerve fiber. Anat Rec. 1907;1:116-28.

11. Breslin S, O'Driscoll L. Three-dimensional cell culture: the missing link in drug discovery. Drug Discov. Today. 2013;18:240-9.

12. Niu N, Wang L. In vitro human cell line models to predict clinical response to anticancer drugs. Pharmacogenomics. 2015;16:273-85.

13. Zhou J, Su J, Fu X, Zheng L, Yin Z. Microfluidic device for primary tumor spheroid isolation. Exp Hematol Oncol. 2017;6:22.

14. Lyu X, Xu H, Song Y, Wu K, Zhao W, Yi M. Organoid technology and applications in cancer research. J Hematol Oncol. 2018;11:116.

15. Lee GY, Kenny PA, Lee EH, Bissell MJ. Three-dimensional culture models of normal and malignant breast epithelial cells. Nat Methods. 2007:4:359-65.

16. Byrne AT, Alférez DG, Amant F, Annibali D, Arribas J, Biankin AV, et al. Interrogating open issues in cancer precision medicine with patient-derived xenografts. Nat Rev Cancer. 2017;17:254-68.

17. Neal JT, Kuo CJ. Organoids as models for neoplastic transformation. Annu Rev Pathol. 2016;11:199-220

18. Ben-David U, Ha G, Tseng Y-Y, Greenwald NF, Oh C, Shih J, et al. Patientderived xenografts undergo mouse-specific tumor evolution. Nat Genet. 2017:49:1567-75.

19. Baker BM, Chen CS. Deconstructing the third dimension: how 3D culture microenvironments alter cellular cues. J Cell Sci. 2012;125:3015-24.

20. Tanner K, Gottesman MM. Beyond 3D culture models of cancer. Sci Transl Med. 2015;7:283ps9.

21. Yamada KM, Cukierman E. Modeling tissue morphogenesis and cancer in 3D. Cell. 2007;130:601-10. 
22. Langhans SA. Three-dimensional in vitro cell culture models in drug discovery and drug repositioning. Front Pharmacol. 2018;9:6.

23. Egeblad M, Nakasone ES, Werb Z. Tumors as organs: complex tissues that interface with the entire organism. Dev Cell. 2010;18:884-901.

24. Ewald AJ, Brenot A, Duong M, Chan BS, Werb Z. Collective epithelial migration and cell rearrangements drive mammary branching morphogenesis. Dev Cell. 2008;14:570-81.

25. McGranahan N, Swanton C. Clonal heterogeneity and tumor evolution: Past, Present, and the Future. Cell. 2017;168:613-28.

26. Tabassum DP, Polyak K. Tumorigenesis: it takes a village. Nat. Rev. Cancer. 2015;15:473-83

27. Caliari SR, Burdick JA. A practical guide to hydrogels for cell culture. Nat. Methods. 2016;13:405-14.

28. Pradhan S, Hassani I, Clary JM, Lipke EA. Polymeric biomaterials for in vitro cancer tissue engineering and drug testing applications. Tissue Eng. - Part B Rev. 2016;22:470-84.

29. Zanoni M, Piccinini F, Arienti C, Zamagni A, Santi S, Polico R, et al. 3D tumor spheroid models for in vitro therapeutic screening: a systematic approach to enhance the biological relevance of data obtained. Sci Rep. 2016;6:19103.

30. Costa EC, Moreira AF, de Melo-Diogo D, Gaspar VM, Carvalho MP, Correia IJ. 3D tumor spheroids: an overview on the tools and techniques used for their analysis. Biotechnol Adv. 2016;34:1427-41.

31. Lenna S, Bellotti C, Duchi S, Martella E, Columbaro M, Dozza B, et al. Mesenchymal stromal cells mediated delivery of photoactive nanoparticles inhibits osteosarcoma growth in vitro and in a murine in vivo ectopic model. J Exp Clin Cancer Res. 2020;39:40.

32. Arai K, Sakamoto R, Kubota D, Kondo T. Proteomic approach toward molecular backgrounds of drug resistance of osteosarcoma cells in spheroid culture system. Proteomics. 2013;13:2351-60.

33. Luo Y, Liu W, Tang P, Jiang D, Gu C, Huang Y, et al. MiR-624-5p promoted tumorigenesis and metastasis by suppressing hippo signaling through targeting PTPRB in osteosarcoma cells. J Exp Clin Cancer Res. 2019;38:488.

34. Rimann M, Laternser S, Gvozdenovic A, Muff R, Fuchs B, Kelm JM, et al. An in vitro osteosarcoma 3D microtissue model for drug development. J Biotechnol. 2014;189:129-35.

35. León IE, Cadavid-Vargas JF, Resasco A, Maschi F, Ayala MA, Carbone C, et al. In vitro and in vivo antitumor effects of the VO-chrysin complex on a new three-dimensional osteosarcoma spheroids model and a xenograft tumor in mice. J Biol Inorg Chem. 2016;21:1009-20.

36. Tan PHS, Aung KZ, Toh SL, Goh JCH, Nathan SS. Three-dimensional porous silk tumor constructs in the approximation of in vivo osteosarcoma physiology. Biomaterials. 2011;32:6131-7.

37. Dey S, Laredj L, Damjanovic K, Muller M, Beard P. Growth of osteosarcoma cells in a three-dimensional bone-like matrix alters their susceptibility to adeno-associated virus. J Gen Virol. 2014;95:1539-43.

38. Kundu B, Bastos ARF, Brancato V, Cerqueira MT, Oliveira JM, Correlo VM, et al. Mechanical property of hydrogels and the presence of adipose stem cells in tumor stroma affect spheroid formation in the 3D osteosarcoma model. ACS Appl Mater Interfaces. 2019;11:14548-59.

39. Voissiere A, Weber V, Gerard Y, Rédini F, Raes F, Chezal JM, et al. Proteoglycan-targeting applied to hypoxia-activated prodrug therapy in chondrosarcoma: first proof-of-concept. Oncotarget. 2017;8:95824-40.

40. Voissiere A, Jouberton E, Maubert E, Degoul F, Peyrode C, Chezal JM, et al. Development and characterization of a human three-dimensional chondrosarcoma culture for in vitro drug testing. PLoS One. 2017;12:e0181340.

41. Monderer D, Luseau A, Bellec A, David E, Ponsolle S, Saiagh S, et al. New chondrosarcoma cell lines and mouse models to study the link between chondrogenesis and chemoresistance. Lab Investig. 2013;93:1100-14.

42. Perut F, Sbrana FV, Avnet S, De Milito A, Baldini N. Spheroid-based 3D cell cultures identify salinomycin as a promising drug for the treatment of chondrosarcoma. J Orthop Res. 2018:36:2305-12.

43. Chien $\mathrm{CS}, \mathrm{Ho} \mathrm{HO}$, Liang YC, Ko PH, Sheu MT, Chen $\mathrm{CH}$. Incorporation of exudates of human platelet-rich fibrin gel in biodegradable fibrin scaffolds for tissue engineering of cartilage. J Biomed Mater Res - Part B Appl Biomater. 2012;100(B):948-55.

44. Hamdi DH, Barbieri S, Chevalier F, Groetz JE, Legendre F, Demoor M, et al. In vitro engineering of human 3D chondrosarcoma: a preclinical model relevant for investigations of radiation quality impact. BMC Cancer. 2015;15:579.

45. Romswinkel A, Infanger M, Dietz C, Strube F, Kraus A. The role of C-X-C chemokine receptor type 4 (CXCR4) in cell adherence and spheroid formation of human Ewing's sarcoma cells under simulated microgravity. Int J Mol Sci. 2019:20:6073.

46. Leuchte K, Altvater B, Hoffschlag S, Potratz J, Meltzer J, Clemens D, et al. Anchorage-independent growth of Ewing sarcoma cells under serum-free conditions is not associated with stem-cell like phenotype and function. Oncol Rep. 2014;32:845-52.

47. Riffle S, Pandey RN, Albert M, Hegde RS. Linking hypoxia, DNA damage and proliferation in multicellular tumor spheroids. BMC Cancer. 2017;17:338.

48. Marchetto A, Ohmura S, Orth MF, Knott MML, Colombo MV, Arrigoni C, et al. Oncogenic hijacking of a developmental transcription factor evokes vulnerability toward oxidative stress in Ewing sarcoma. Nat Commun. 2020; $11: 2423$.

49. Santoro M, Menegaz BA, Lamhamedi-Cherradi SE, Molina ER, Wu D, Priebe $W$, et al. Modeling stroma-induced drug resistance in a tissue-engineered tumor model of Ewing sarcoma. Tissue Eng Part A. 2017:23:80-9.

50. Fong ELS, Lamhamedi-Cherradi SE, Burdett E, Ramamoorthy V, Lazar AJ, Kasper FK, et al. Modeling Ewing sarcoma tumors in vitro with 3D scaffolds. Proc Natl Acad Sci U S A. 2013;110:6500-5.

51. Santoro M, Lamhamedi-Cherradi SE, Menegaz BA, Ludwig JA, Mikos AG. Flow perfusion effects on three-dimensional culture and drug sensitivity of Ewing sarcoma. Proc Natl Acad Sci U S A. 2015;112:10304-9.

52. Villasante A, Marturano-Kruik A, Vunjak-Novakovic G. Bioengineered human tumor within a bone niche. Biomaterials. 2014;35:5785-94.

53. Codenotti S, Faggi F, Ronca R, Chiodelli P, Grillo E, Guescini M, et al. Caveolin-1 enhances metastasis formation in a human model of embryonal rhabdomyosarcoma through Erk signaling cooperation. Cancer Lett. 2019; 449:135-44.

54. Dolatabadi S, Jonasson E, Lindén M, Fereydouni B, Bäcksten K, Nilsson M, et al. JAK-STAT signalling controls cancer stem cell properties including chemotherapy resistance in myxoid liposarcoma. Int J Cancer. 2019;145: 435-49.

55. Patra B, Lafontaine J, Bavoux M, Zerouali K, Glory A, Ahanj M, et al. On-chip combined radiotherapy and chemotherapy testing on soft-tissue sarcoma spheroids to study cell death using flow cytometry and clonogenic assay. Sci Rep. 2019;9.

56. Tornin J, Hermida-Prado F, Padda RS, Gonzalez MV, Alvarez-Fernandez C, Rey V, et al. FUS-CHOP promotes invasion in myxoid liposarcoma through a SRC/ FAK/RHO/ROCK-dependent pathway. Neoplasia (United States). 2018;20:44-56

57. Miserocchi G, De Vita A, Mercatali L, Recine F, Liverani C, Spadazzi C, et al. Characterization and drug sensitivity of a new high-grade myxofibrosarcoma cell line. Cells. 2018;7:186.

58. Wang J, Quach A, Brasch ME, Turner CE, Henderson JH. On-command on/ off switching of progenitor cell and cancer cell polarized motility and aligned morphology via a cytocompatible shape memory polymer scaffold. Biomaterials. 2017;140:150-61.

59. Pozzobon M, Saggioro M, D’Agostino S, Bisogno G, Muraca M, Gamba P. Alveolar rhabdomyosarcoma decellularization. Methods Mol Biol. 2018;1577: 317-25

60. Zhang Z, Wang H, Ding Q, Xing Y, Xu Z, Lu C, et al. Establishment of patient-derived tumor spheroids for non-small cell lung cancer. PLoS One. 2018:13:e0194016.

61. Reynolds DS, Tevis KM, Blessing WA, Colson YL, Zaman MH, Grinstaff MW. Breast cancer spheroids reveal a differential cancer stem cell response to chemotherapeutic treatment. Sci Rep. 2017;7:10382.

62. Witusik-Perkowska M, Rieske P, Hułas-Bigoszewska K, Zakrzewska M, Stawski R, Kulczycka-Wojdala D, et al. Glioblastoma-derived spheroid cultures as an experimental model for analysis of EGFR anomalies. J Neurooncol. 2011;102: 395-407.

63. Chambers KF, Mosaad EMO, Russell PJ, Clements JA, Doran MR. 3D cultures of prostate cancer cells cultured in a novel high-throughput culture platform are more resistant to chemotherapeutics compared to cells cultured in monolayer. PLoS One. 2014;9:e111029.

64. Ward JP, King JR. Mathematical modelling of avascular-tumour growth. IMA J Math Appl Med Biol. 1997;14:39-69.

65. Friedrich J, Ebner R, Kunz-Schughart LA. Experimental anti-tumor therapy in 3-D: spheroids--old hat or new challenge? Int J Radiat Biol. 2007;83:849-71.

66. Kunz-Schughart LA, Freyer JP, Hofstaedter F, Ebner R. The use of 3D cultures for high-throughput screening: the multicellular spheroid model. J Biomol Screen. 2004:9:273-85.

67. Vinci M, Gowan S, Boxall F, Patterson L, Zimmermann M, Court W, et al. Advances in establishment and analysis of three-dimensional tumor 
spheroid-based functional assays for target validation and drug evaluation. BMC Biol. 2012:10:29.

68. Costa EC, Gaspar VM, Coutinho P, Correia IJ. Optimization of liquid overlay technique to formulate heterogenic 3D co-cultures models. Biotechnol Bioeng. 2014;111:1672-85.

69. Nunes AS, Barros AS, Costa EC, Moreira AF, Correia IJ. 3D tumor spheroids as in vitro models to mimic in vivo human solid tumors resistance to therapeutic drugs. Biotechnol Bioeng. 2019;116:206-26.

70. Tesei A, Sarnelli A, Arienti C, Menghi E, Medri L, Gabucci E, et al. In vitro irradiation system for radiobiological experiments. Radiat Oncol. 2013;8:257.

71. Jeanes A, Gottardi CJ, Yap AS. Cadherins and cancer: How does cadherin dysfunction promote tumor progression? Oncogene. 2008;27:6920-9.

72. Nederman T, Glimelius B, Norling B, Carlsson J, Brunk U. Demonstration of an extracellular matrix in multicellular tumor spheroids. Cancer Res. 1984;44: 3090-7.

73. Tannock IF, Lee CM, Tunggal JK, Cowan DSM, Egorin MJ. Limited penetration of anticancer drugs through tumor tissue: a potential cause of resistance of solid tumors to chemotherapy. Clin Cancer Res. 2002;8:878-84.

74. Trédan O, Galmarini CM, Patel K, Tannock IF. Drug resistance and the solid tumor microenvironment. J Natl Cancer Inst. 2007;99:1441-54.

75. Minchinton Al, Tannock IF. Drug penetration in solid tumours. Nat. Rev. Cancer. 2006;6:583-92.

76. Warburg O, Wind F, Negelein E. The metabolism of tumors in the body. J Gen Physiol. 1927:8:519-30

77. Carlsson J, Acker H. Relations between $\mathrm{pH}$, oxygen partial pressure and growth in cultured cell spheroids. Int J Cancer. 1988;42:715-20.

78. Hirschhaeuser F, Menne H, Dittfeld C, West J, Mueller-Klieser W, KunzSchughart LA. Multicellular tumor spheroids: an underestimated tool is catching up again. J Biotechnol. 2010;148:3-15.

79. Estrella V, Chen T, Lloyd M, Wojtkowiak J, Cornnell HH, Ibrahim-Hashim A, et al. Acidity generated by the tumor microenvironment drives local invasion. Cancer Res. 2013;73:1524-35.

80. Huber V, Camisaschi C, Berzi A, Ferro S, Lugini L, Triulzi T, et al. Cancer acidity: An ultimate frontier of tumor immune escape and a novel target of immunomodulation. Semin Cancer Biol. Academic Press. 2017;43:74-89.

81. Cowan DS, Tannock IF. Factors that influence the penetration of methotrexate through solid tissue. Int J cancer. 2001;91:120-5.

82. Swietach P, Hulikova A, Patiar S, Vaughan-Jones RD, Harris AL. Importance of intracellular $\mathrm{pH}$ in determining the uptake and efficacy of the weakly basic chemotherapeutic drug, doxorubicin. PLoS One. 2012;7:e35949.

83. Wojtkowiak JW, Verduzco D, Schramm KJ, Gillies RJ. Drug resistance and cellular adaptation to tumor acidic pH microenvironment. Mol Pharm. 2011; 8:2032-8.

84. Cheung-Ong K, Giaever G, Nislow C. DNA-damaging agents in cancer chemotherapy: serendipity and chemical biology. Chem. Biol. 2013;20:648-59.

85. Mitchison TJ. The proliferation rate paradox in antimitotic chemotherapy. Mol Biol Cell. 2012;23:1-6.

86. Sonveaux P. ROS and radiotherapy: more we care. Oncotarget. 2017;8:35482-3.

87. Weiswald LB, Bellet $D$, Dangles-Marie V. Spherical cancer models in tumor biology. Neoplasia. 2015;17:1-15.

88. Durand RE, Olive PL. Resistance of tumor cells to chemo- and radiotherapy modulated by the three-dimensional architecture of solid tumors and spheroids. Methods Cell Biol. 2001;64:211-33.

89. Carragher N, Piccinini F, Tesei A, Trask OJ, Bickle M, Horvath P. Concerns, challenges and promises of high-content analysis of 3D cellular models. Nat Rev Drug Discov. 2018;17:606.

90. Friedrich J, Seidel C, Ebner R, Kunz-Schughart LA. Spheroid-based drug screen: considerations and practical approach. Nat Protoc. 2009;4:309-24.

91. S Franco S, Szczesna K, lliou MS, Al-Qahtani M, Mobasheri A, Kobolák J, et al. In vitro models of cancer stem cells and clinical applications. BMC Cancer. 2016;16:738

92. Lapidot T, Sirard C, Vormoor J, Murdoch B, Hoang T, Caceres-Cortes J, et al. A cell initiating human acute myeloid leukaemia after transplantation into SCID mice. Nature. 1994;367(6464):645-8.

93. Clevers $\mathrm{H}$. The cancer stem cell: premises, promises and challenges. Nat Med. 2011;17:313-9.

94. Pastrana E, Silva-Vargas V, Doetsch F. Eyes wide open: a critical review of sphere-formation as an assay for stem cells. Cell Stem Cell. 2011;8:486-98.

95. Valent P, Bonnet D, De Maria R, Lapidot T, Copland M, Melo JV, et al. Cancer stem cell definitions and terminology: the devil is in the details. Nat Rev Cancer. 2012;12:767-75.
96. Clarke MF, Dick JE, Dirks PB, Eaves CJ, Jamieson CHM, Jones DL, et al. Cancer stem cells - perspectives on current status and future directions: AACR workshop on cancer stem cells. Cancer Res. 2006;66:9339-44.

97. Zhou B-BS, Zhang H, Damelin M, Geles KG, Grindley JC, Dirks PB. Tumourinitiating cells: challenges and opportunities for anticancer drug discovery. Nat Rev Drug Discov. 2009:8:806-23.

98. Pattabiraman DR, Weinberg RA. Tackling the cancer stem cells - What challenges do they pose? Nat Rev Drug Discov. 2014;13:497-512.

99. Clark DW, Palle K. Aldehyde dehydrogenases in cancer stem cells: potential as therapeutic targets. Ann Transl Med. 2016;4:518-518.

100. Schulz A, Meyer F, Dubrovska A, Borgmann K. Cancer stem cells and radioresistance: DNA repair and beyond. Cancers (Basel). 2019;11(6):862.

101. Abdullah LN, Chow EK-H. Mechanisms of chemoresistance in cancer stem cells. Clin Transl Med. 2013;2:3.

102. Balkwill FR, Capasso M, Hagemann T. The tumor microenvironment at a glance. J Cell Sci. 2012;125:5591-6.

103. Correia AL, Bissell MJ. The tumor microenvironment is a dominant force in multidrug resistance. Drug Resist Updat. 2012;15:39-49.

104. McMillin DW, Delmore J, Weisberg E, Negri JM, Geer DC, Klippel S, et al. Tumor cell-specific bioluminescence platform to identify stroma-induced changes to anticancer drug activity. Nat Med. 2010;16:483-9.

105. Lao Z, Kelly CJ, Yang X-Y, Jenkins WT, Toorens E, Ganguly T, et al. Improved methods to generate spheroid cultures from tumor cells, tumor cells \& fibroblasts or tumor fragments: Microenvironment. Microvesicles and MiRNA. PLoS One. 2015;10:e0133895.

106. Lamichhane SP, Arya N, Kohler E, Xiang S, Christensen J, Shastri VP. Recapitulating epithelial tumor microenvironment in vitro using three dimensional tri-culture of human epithelial, endothelial, and mesenchymal cells. BMC Cancer. 2016;16:581.

107. Rodríguez CE, Moverer LM, Reidel SI, Marino L, de Kier Joffé EDB, Jasnis MA, et al. Abstract 2881: cytotoxic effect of trastuzumab on macrophageinfiltrated human mammary tumor spheroids. Cancer Res. American Association for Cancer Research (AACR). 2012;72:2881-1.

108. McMillin DW, Negri JM, Mitsiades CS. The role of tumour-stromal interactions in modifying drug response: challenges and opportunities. Nat Rev Drug Discov. 2013;12:217-28.

109. Majety M, Pradel LP, Gies M, Ries CH. Fibroblasts influence survival and therapeutic response in a 3D co-culture model. PLoS One. 2015;10: e0127948.

110. Lee J-H, Kim S-K, Khawar IA, Jeong S-Y, Chung S, Kuh H-J. Microfluidic coculture of pancreatic tumor spheroids with stellate cells as a novel 3D model for investigation of stroma-mediated cell motility and drug resistance. J Exp Clin Cancer Res. 2018;37:4.

111. Hoffmann OI, IImberger C, Magosch S, Joka M, Jauch K-W, Mayer B. Impact of the spheroid model complexity on drug response. J Biotechnol. 2015;205:14-23.

112. Clevers H. Modeling development and disease with organoids. Cell. 2016; 165:1586-97.

113. Park SE, Georgescu A, Huh D. Organoids-on-a-chip. Science. 2019;364:960-5.

114. Tuveson D, Clevers H. Cancer modeling meets human organoid technology. Science. 2019;364:952-5.

115. Kretzschmar K. Clevers H. Organoids: modeling development and the stem cell niche in a dish. Dev. Cell. Cell Press. 2016:590-600.

116. Bleijs $M$, Wetering $M$, Clevers $H$, Drost J. Xenograft and organoid model systems in cancer research. EMBO J. 2019;38:e101654.

117. Van De Wetering $M$, Francies $H E$, Francis JM, Bounova $G$, lorio F, Pronk $A$, et al. Prospective derivation of a living organoid biobank of colorectal cancer patients. Cell. 2015;161:933-45.

118. Sachs N, de Ligt J, Kopper O, Gogola E, Bounova G, Weeber F, et al. A Living biobank of breast cancer organoids captures disease heterogeneity. Cell. 2018:172:373-86 e10.

119. Nanki K, Toshimitsu K, Takano A, Fujii M, Shimokawa M, Ohta Y, et al. Divergent routes toward Wnt and R-spondin niche independency during human gastric carcinogenesis. Cell. 2018;174:856-69 e17.

120. Smith RC, Tabar V. Constructing and deconstructing cancers using human pluripotent stem cells and organoids. Cell Stem Cell. 2019;24:12-24.

121. Múnera JO, Sundaram N, Rankin SA, Hill D, Watson C, Mahe M, et al. Differentiation of human pluripotent stem cells into colonic organoids via transient activation of BMP signaling. Cell Stem Cell. 2017;21:51-64 e6.

122. Miura S, Suzuki A. Generation of mouse and human organoid-forming intestinal progenitor cells by direct lineage reprogramming. Cell Stem Cell. 2017;21:456-71 e5. 
123. Sato $T$, Stange DE, Ferrante $M$, Vries RGJ, Van Es JH, Van Den Brink S, et al. Long-term expansion of epithelial organoids from human colon, adenoma, adenocarcinoma, and Barrett's epithelium. Gastroenterology. 2011;141:1762-72

124. Fujii M, Matano M, Toshimitsu K, Takano A, Mikami Y, Nishikori S, et al. Human intestinal organoids maintain self-renewal capacity and cellular diversity in niche-inspired culture condition. Cell Stem Cell. 2018;23: 787-93 e6.

125. Fujii M, Shimokawa M, Date S, Takano A, Matano M, Nanki K, et al. A colorectal tumor organoid library demonstrates progressive loss of niche factor requirements during tumorigenesis. Cell Stem Cell. 2016;18:827-38.

126. Qu Y, Han B, Gao B, Bose S, Gong Y, Wawrowsky K, et al. Differentiation of human induced pluripotent stem cells to mammary-like organoids. Stem Cell Reports. 2017:8:205-15.

127. Hu H, Gehart H, Artegiani B, LÖpez-Iglesias C, Dekkers F, Basak O, et al. Long-term expansion of functional mouse and human hepatocytes as 3D organoids. Cell. 2018;175:1591-606 e19.

128. Broutier L, Mastrogiovanni G, Verstegen MM, Francies HE, Gavarró LM, Bradshaw CR, et al. Human primary liver cancer-derived organoid cultures for disease modeling and drug screening. Nat Med. 2017;23:1424-35.

129. Miller AJ, Dye BR, Ferrer-Torres D, Hill DR, Overeem AW, Shea LD, et al. Generation of lung organoids from human pluripotent stem cells in vitro. Nat Protoc. 2019;14:518-40.

130. Kim M, Mun H, Sung CO, Cho EJ, Jeon HJ, Chun SM, et al. Patient-derived lung cancer organoids as in vitro cancer models for therapeutic screening. Nat Commun. 2019;10

131. Hohwieler M, Illing A, Hermann PC, Mayer T, Stockmann M, Perkhofer L et al. Human pluripotent stem cell-derived acinar/ductal organoids generate human pancreas upon orthotopic transplantation and allow disease modelling. Gut. 2017:66:473-86.

132. Boj SF, II HC, Baker LA, IIC C, Engle DD, Corbo V, et al. Organoid models of human and mouse ductal pancreatic cancer. Cell. 2015;160:324-38.

133. Boretto M, Maenhoudt N, Luo X, Hennes A, Boeckx B, Bui B, et al. Patientderived organoids from endometrial disease capture clinical heterogeneity and are amenable to drug screening. Nat Cell Biol. 2019;21:1041-51.

134. McCracken KW, Catá EM, Crawford CM, Sinagoga KL, Schumacher M, Rockich $B E$, et al. Modelling human development and disease in pluripotent stem-cell-derived gastric organoids. Nature. 2014:516:400-4.

135. Seidlitz T, Merker SR, Rothe A, Zakrzewski F, von Neubeck C, Grützmann K, et al. Human gastric cancer modelling using organoids. Gut. 2019;68:207-17.

136. Karthaus WR, laquinta PJ, Drost J, Gracanin A, Van Boxtel R, Wongvipat J, et al. Identification of multipotent luminal progenitor cells in human prostate organoid cultures. Cell. 2014;159:163-75.

137. Gao D, Vela I, Sboner A, laquinta PJ, Karthaus WR, Gopalan A, et al. Organoid cultures derived from patients with advanced prostate cancer. Cell. 2014;159:176-87.

138. Kopper O, de Witte CJ, Lõhmussaar K, Valle-Inclan JE, Hami N, Kester L, et al. An organoid platform for ovarian cancer captures intra- and interpatient heterogeneity. Nat Med. 2019;25:838-49.

139. Horsley H, Dharmasena D, Malone-Lee J, Rohn JL. A urine-dependent human urothelial organoid offers a potential alternative to rodent models of infection. Sci Rep. 2018;8:1238.

140. Lee SH, Hu W, Matulay JT, Silva MV, Owczarek TB, Kim K, et al. Tumor evolution and drug response in patient-derived organoid models of bladder cancer. Cell. 2018;173:515-28 e17.

141. Czerniecki SM, Cruz NM, Harder JL, Menon R, Annis J, Otto EA, et al. Highthroughput screening enhances kidney organoid differentiation from human pluripotent stem cells and enables automated multidimensional phenotyping. Cell Stem Cell. 2018;22:929-40 e4.

142. Schutgens F, Rookmaaker MB, Margaritis T, Rios A, Ammerlaan C, Jansen J, et al. Tubuloids derived from human adult kidney and urine for personalized disease modeling. Nat Biotechnol. 2019:37:303-13.

143. Calandrini C, Schutgens F, Oka R, Margaritis T, Candelli T, Mathijsen L, et al. An organoid biobank for childhood kidney cancers that captures disease and tissue heterogeneity. Nat Commun. 2020;11:1310.

144. Velasco S, Kedaigle AJ, Simmons SK, Nash A, Rocha M, Quadrato G, et al. Individual brain organoids reproducibly form cell diversity of the human cerebral cortex. Nature. 2019;570:523-7.

145. Jacob F, Salinas RD, Zhang DY, Nguyen PTT, Schnoll JG, Wong SZH, et al. A patient-derived glioblastoma organoid model and biobank recapitulates inter- and intra-tumoral heterogeneity. Cell. 2020;180:188-204 e22.
146. Kale S, Biermann S, Edwards C, Tarnowski C, Morris M, Long MW. Threedimensional cellular development is essential for ex vivo formation of human bone. Nat Biotechnol. 2000;18:954-8.

147. Lee DF, Su J, Kim HS, Chang B, Papatsenko D, Zhao R, et al. Modeling familial cancer with induced pluripotent stem cells. Cell. 2015;161:240-54.

148. Trisno SL, Philo KED, McCracken KW, Catá EM, Ruiz-Torres S, Rankin SA, et al. Esophageal organoids from human pluripotent stem cells delineate Sox2 functions during esophageal specification. Cell Stem Cell. 2018;23:501-15 e7.

149. Li X, Francies HE, Secrier M, Perner J, Miremadi A, Galeano-Dalmau N, et al. Organoid cultures recapitulate esophageal adenocarcinoma heterogeneity providing a model for clonality studies and precision therapeutics. Nat Commun. 2018:9:2983.

150. Meng Q. Three-dimensional culture of hepatocytes for prediction of drug induced hepatotoxicity. Expert Opin Drug Metab Toxicol. 2010;6:733-46.

151. Katsuda T, Kawamata M, Hagiwara K, Takahashi R-U, Yamamoto Y, Camargo FD, et al. Conversion of terminally committed hepatocytes to culturable bipotent progenitor cells with regenerative capacity. Cell Stem Cell. 2017;20:41-55.

152. Huch M, Gehart H, van Boxtel R, Hamer K, Blokzijl F, Verstegen MMA, et al. Long-term culture of genome-stable bipotent stem cells from adult human liver. Cell. 2015;160:299-312.

153. Eder A, Vollert I, Hansen A, Eschenhagen T. Human engine human engineered heart tissue as a model system for drug testing. Adv Drug Deliv Rev. 2015;96:214-24.

154. Takasato M, Er PX, Chiu HS, Maier B, Baillie GJ, Ferguson C, et al. Kidney organoids from human iPS cells contain multiple lineages and model human nephrogenesis. Nature. 2015;526:564-8.

155. Cristobal $A$, van den Toorn HWP, van de Wetering $M$, Clevers $H$, Heck AJR, Mohammed S. Personalized proteome profiles of healthy and tumor human colon organoids reveal both individual diversity and basic features of colorectal cancer. Cell Rep. 2017;18:263-74.

156. Roerink SF, Sasaki N, Lee-Six H, Young MD, Alexandrov LB, Behjati S, et al. Intra-tumour diversification in colorectal cancer at the single-cell level. Nature. 2018;556:437-62.

157. Stratton MR, Campbell PJ, Futreal PA. The cancer genome. Nature. 2009; 458(7239):719-24

158. Matano M, Date S, Shimokawa M, Takano A, Fujii M, Ohta Y, et al. Modeling colorectal cancer using CRISPR-Cas9-mediated engineering of human intestinal organoids. Nat Med. 2017;21:256-62.

159. Drost J, van Boxtel R, Blokzijl F, Mizutani T, Sasaki N, Sasselli V, et al. Use of CRISPR-modified human stem cell organoids - supplements. Science (80- ). 2017;238:eaao3130.

160. Drost J, Van Jaarsveld RH, Ponsioen B, Zimberlin C, Van Boxtel R, Buijs A, et al. Sequential cancer mutations in cultured human intestinal stem cells. Nature. 2015:521:43-7.

161. Fumagalli A, Drost J, Suijkerbuijk SJE, van Boxtel R, de Ligt J, Offerhaus GJ, et al. Genetic dissection of colorectal cancer progression by orthotopic transplantation of engineered cancer organoids. Proc Natl Acad Sci U S A. 2017;114:E2357-64.

162. Fumagalli A, Suijkerbuijk SJE, Begthel H, Beerling E, Oost KC, Snippert HJ, et al A surgical orthotopic organoid transplantation approach in mice to visualize and study colorectal cancer progression. Nat Protoc. 2018;13:235-47.

163. Seino T, Kawasaki S, Shimokawa M, Tamagawa H, Toshimitsu K, Fujii M, et al. Human pancreatic tumor organoids reveal loss of stem cell niche factor dependence during disease progression. Cell Stem Cell. 2018;22:454-67 e6.

164. Cheung KJ, Gabrielson E, Werb Z, Ewald AJ. Collective invasion in breast cancer requires a conserved basal epithelial program. Cell. 2013;155:1639-51.

165. Wu J-S, Li Z-F, Wang H-F, Yu X-H, Pang X, Wu J-B, et al. Cathepsin B defines leader cells during the collective invasion of salivary adenoid cystic carcinoma. Int J Oncol. 2019:54:1233-44.

166. Libanje F, Raingeaud J, Luan R, Thomas Z, Zajac O, Veiga J, et al. ROCK2 inhibition triggers the collective invasion of colorectal adenocarcinomas. EMBO J. 2019;38:e99299.

167. Risbridger GP, Toivanen R, Taylor RA. Preclinical models of prostate cancer: patient-derived xenografts, organoids, and other explant models. Cold Spring Harb Perspect Med. 2018;8:a030536.

168. Junttila MR, De Sauvage FJ. Influence of tumour micro-environment heterogeneity on therapeutic response. Nature. 2013;501(7467):346-54.

169. Belgodere JA, King CT, Bursavich JB, Burow ME, Martin EC, Jung JP. Engineering breast cancer microenvironments and 3D bioprinting. Front. Bioeng. Biotechnol. 2018;6:66 
170. Fan H, Demirci U, Chen P. Emerging organoid models: leaping forward in cancer research. J. Hematol. Oncol. 2019;12(1):142.

171. Mellman I, Coukos G, Dranoff G. Cancer immunotherapy comes of age. Nature. 2011:480:480-9.

172. Zumwalde NA, Haag JD, Sharma D, Mirrielees JA, Wilke LG, Gould MN, et al. Analysis of immune cells from human mammary ductal epithelial organoids reveals V $82+T$ cells that efficiently target breast carcinoma cells in the presence of bisphosphonate. Cancer Prev Res (Phila). 2016;9:305-16.

173. Finnberg NK, Gokare P, Lev A, Grivennikov SI, MacFarlane AW, Campbell KS, et al. Application of 3D tumoroid systems to define immune and cytotoxic therapeutic responses based on tumoroid and tissue slice culture molecular signatures. Oncotarget. 2017;8:66747-57.

174. Jenkins RW, Aref AR, Lizotte PH, Ivanova E, Stinson S, Zhou CW, et al. Ex vivo profiling of PD-1 blockade using organotypic tumor spheroids. Cancer Discov. 2018;8:196-215.

175. Neal JT, Li X, Zhu J, Giangarra V, Grzeskowiak CL, Ju J, et al. Organoid modeling of the tumor immune microenvironment. Cell. 2018;175:1972-88 e16.

176. Chakrabarti J, Holokai L, Syu L, Steele N, Chang J, Dlugosz A, et al. Mousederived gastric organoid and immune cell co-culture for the study of the tumor microenvironment. Methods Mol Biol. 2018;1817:157-68.

177. Dijkstra KK, Cattaneo CM, Weeber F, Chalabi M, van de Haar J, Fanchi LF, et al. Generation of tumor-reactive T cells by co-culture of peripheral blood lymphocytes and tumor organoids. Cell. 2018;174:1586-98 e12.

178. Schnalzger TE, de Groot MH, Zhang C, Mosa MH, Michels BE, Röder J, et al. 3D model for CAR-mediated cytotoxicity using patient-derived colorectal cancer organoids. EMBO J. 2019;38:e100928.

179. Öhlund D, Handly-Santana A, Biffi G, Elyada E, Almeida AS, Ponz-Sarvise M, et al. Distinct populations of inflammatory fibroblasts and myofibroblasts in pancreatic cancer. J Exp Med. 2017;214:579-96.

180. Wimmer RA, Leopoldi A, Aichinger M, Wick N, Hantusch B, Novatchkova M, et al. Human blood vessel organoids as a model of diabetic vasculopathy. Nature. 2019;565:505-10.

181. Wang YI, Carmona C, Hickman JJ, Shuler ML. Multiorgan microphysiological systems for drug development: strategies, advances, and challenges. Adv Healthc Mater. 2018;7(2):170100.

182. Sung JH, Wang YI, Narasimhan Sriram N, Jackson M, Long C, Hickman $\mathrm{JJ}$, et al. Recent advances in body-on-a-chip systems. Anal. Chem. 2019; 91:330-51.

183. Ebrahimkhani MR, Young $C L$, Lauffenburger DA, Griffith LG, Borenstein JT. Approaches to in vitro tissue regeneration with application for human disease modeling and drug development. Drug Discov. Today. 2014;19:754-62.

184. Benam KH, Dauth S, Hassell B, Herland A, Jain A, Jang K-J, et al. Engineered in vitro disease models. Annu Rev Pathol Mech Dis. 2015;10:195-262.

185. Shirure VS, Bi Y, Curtis MB, Lezia A, Goedegebuure MM, Goedegebuure SP, et al. Tumor-on-a-chip platform to investigate progression and drug sensitivity in cell lines and patient-derived organoids. Lab Chip. 2018;18: 3687-702.

186. Skardal A, Murphy SV, Devarasetty M, Mead I, Kang HW, Seol YJ, et al. Multitissue interactions in an integrated three-tissue organ-on-a-chip platform. Sci Rep. 2017;7:8837.

187. Xu Z, Li E, Guo Z, Yu R, Hao H, Xu Y, et al. Design and construction of a multi-organ microfluidic chip mimicking the in vivo microenvironment of lung cancer metastasis. ACS Appl Mater Interfaces. 2016;8:25840-7.

188. Workman P, Aboagye EO, Balkwill F, Balmain A, Bruder G, Chaplin DJ, et al. Guidelines for the welfare and use of animals in cancer research. $\mathrm{Br} J$ Cancer. 2010;102:1555-77.

189. Galuschka C, Proynova R, Roth B, Augustin HG, Müller-Decker K. Models in translational oncology: a public resource database for preclinical cancer research. Cancer Res. 2017;77:2557-63.

190. Gonzalez C. Drosophila melanogaster: a model and a tool to investigate malignancy and identify new therapeutics. Nat Rev Cancer. 2013;13:172-83.

191. Potts MB, Cameron S. Cell lineage and cell death: Caenorhabditis elegans and cancer research. Nat Rev Cancer. 2011;11:50-8.

192. Nutt LK. The Xenopus oocyte: a model for studying the metabolic regulation of cancer cell death. Semin Cell Dev Biol. 2012;23:412-8.

193. White R, Rose K, Zon L. Zebrafish cancer: the state of the art and the path forward. Nat Rev Cancer. 2013;13:624-36.

194. Letrado P, de Miguel I, Lamberto I, Díez-Martínez R, Oyarzabal J. Zebrafish: Speeding up the cancer drug discovery process. Cancer Res. 2018;78:6048-58.
195. Cagan RL, Zon LI, White RM. Modeling cancer with flies and fish. Dev. Cell. 2019:49:317-24

196. Stoletov K, Klemke R. Catch of the day: zebrafish as a human cancer model. Oncogene. 2008;27:4509-20.

197. Berghmans S, Murphey RD, Wienholds E, Neuberg D, Kutok JL, Fletcher CDM, et al. tp53 mutant zebrafish develop malignant peripheral nerve sheath tumors. Proc Natl Acad Sci U S A. 2005;102:407-12.

198. Wyatt RA, Trieu NPV, Crawford BD. Zebrafish xenograft: an evolutionary experiment in tumour biology. Genes (Basel). 2017;8(9):220.

199. Paul CD, Bishop K, Devine A, Paine EL, Staunton JR, Thomas SM, et al. Tissue architectural cues drive organ targeting of tumor cells in zebrafish. Cell Syst. 2019;9:187-206 e16.

200. Konantz M, Balci TB, Hartwig UF, Dellaire G, André MC, Berman JN, et al. Zebrafish xenografts as a tool for in vivo studies on human cancer. Ann N Y Acad Sci. 2012:1266:124-37.

201. Vargas-Patron LA, Agudelo-Dueñas N, Madrid-Wolff J, Venegas JA, González $J M$, Forero-Shelton $\mathrm{M}$, et al. Xenotransplantation of human glioblastoma in zebrafish larvae: in vivo imaging and proliferation assessment. Biol Open. 2019:8(5):bio043257.

202. Yoshida GJ. Applications of patient-derived tumor xenograft models and tumor organoids. J. Hematol. Oncol. 2020;13(1):4.

203. Gao H, Korn JM, Ferretti S, Monahan JE, Wang Y, Singh M, et al. Highthroughput screening using patient-derived tumor xenografts to predict clinical trial drug response. Nat Med. 2015;21:1318-25.

204. Hidalgo M, Amant F, Biankin AV, Budinská E, Byrne AT, Caldas C, et al. Patient-derived xenograft models: an emerging platform for translational cancer research. Cancer Discov. 2014;4:998-1013.

205. Kemper K, Krijgsman O, Cornelissen-Steijger P, Shahrabi A, Weeber F, Song $J-Y$, et al. Intra- and inter-tumor heterogeneity in a vemurafenib-resistant melanoma patient and derived xenografts. EMBO Mol Med. 2015;7:1104-18.

206. Morgan KM, Riedlinger GM, Rosenfeld J, Ganesan S, Pine SR. Patient-derived xenograft models of non-small cell lung cancer and their potential utility in personalized medicine. Front Oncol. 2017;7:2.

207. Julien S, Merino-Trigo A, Lacroix L, Pocard M, Goéré D, Mariani P, et al. Characterization of a large panel of patient-derived tumor xenografts representing the clinical heterogeneity of human colorectal cancer. Clin Cancer Res. 2012;18:5314-28.

208. Rosfjord E, Lucas J, Li G, Gerber H-P. Advances in patient-derived tumor xenografts: from target identification to predicting clinical response rates in oncology. Biochem Pharmacol. 2014;91:135-43.

209. Pearson AT, Finkel KA, Warner KA, Nör F, Tice D, Martins MD, et al. Patientderived xenograft (PDX) tumors increase growth rate with time. Oncotarget. 2016;7:7993-8005.

210. Hoffman RM. Patient-derived orthotopic xenografts: better mimic of metastasis than subcutaneous xenografts. Nat Rev Cancer. 2015;15:451-2.

211. Dai L, Lu C, Yu XI, Dai L-J, Zhou JX. Construction of orthotopic xenograft mouse models for human pancreatic cancer. Exp Ther Med. 2015;10:1033-8.

212. Zhan B, Wen S, Lu J, Shen G, Lin X, Feng J, et al. Identification and causes of metabonomic difference between orthotopic and subcutaneous xenograft of pancreatic cancer. Oncotarget. 2017:8:61264-81.

213. Shultz LD, Brehm MA, Victor Garcia-Martinez J, Greiner DL. Humanized mice for immune system investigation: progress, promise and challenges. Nat. Rev. Immunol. 2012;12:786-98.

214. Wege AK, Ernst W, Eckl J, Frankenberger B, Vollmann-Zwerenz A, Männel DN, et al. Humanized tumor mice-a new model to study and manipulate the immune response in advanced cancer therapy. Int J Cancer. 2011;129: 2194-206.

\section{Publisher's Note}

Springer Nature remains neutral with regard to jurisdictional claims in published maps and institutional affiliations. 